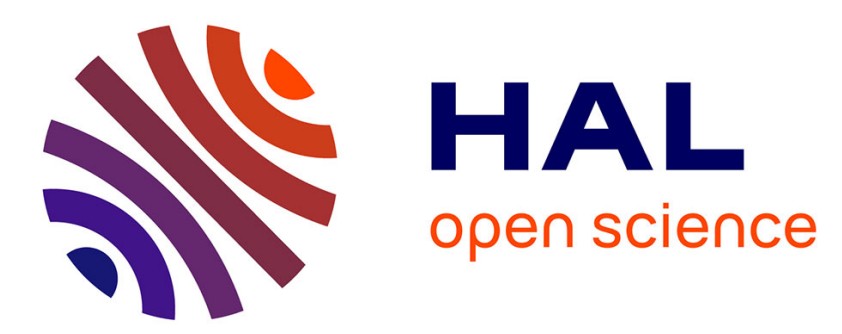

\title{
Either taking it easy or feeling too tired: old Cory's Shearwaters display reduced activity levels while at sea
}

Paulo Catry, José Pedro Granadeiro, Jaime Ramos, Richard A. Phillips, Paulo Oliveira

\section{- To cite this version: \\ Paulo Catry, José Pedro Granadeiro, Jaime Ramos, Richard A. Phillips, Paulo Oliveira. Either taking it easy or feeling too tired: old Cory's Shearwaters display reduced activity levels while at sea. Journal für Ornithologie $=$ Journal of Ornithology, 2010, 152 (3), pp.549-555. 10.1007/s10336-010-0616-7. hal-00646464}

\section{HAL Id: hal-00646464 https://hal.science/hal-00646464}

Submitted on 30 Nov 2011

HAL is a multi-disciplinary open access archive for the deposit and dissemination of scientific research documents, whether they are published or not. The documents may come from teaching and research institutions in France or abroad, or from public or private research centers.
L'archive ouverte pluridisciplinaire HAL, est destinée au dépôt et à la diffusion de documents scientifiques de niveau recherche, publiés ou non, émanant des établissements d'enseignement et de recherche français ou étrangers, des laboratoires publics ou privés. 
1 Either taking it easy or feeling too tired: old Cory's Shearwaters display reduced

2 activity levels while at sea.

3

4 Paulo Catry ${ }^{1,2^{*}}$, José Pedro Granadeiro ${ }^{2}$, Jaime Ramos ${ }^{3}$, Richard A. Phillips ${ }^{4}$, Paulo

5 Oliveira $^{5}$

6

7

$8 \quad{ }^{1}$ Eco-Ethology Research Unit \& Centro de Biociências, ISPA, Rua Jardim do Tabaco

9 34, 1149-041 Lisboa, Portugal.

102 - Centro de Biologia Ambiental, Museu Nacional de História Natural, Rua da Escola

11 Politécnica, Lisboa, Portugal

123 - IMAR-Institute of Marine Research, Department of Zoology, University of

13 Coimbra, Portugal

144 - British Antarctic Survey, Natural Environment Research Council, High Cross,

15 Madingley Road, Cambridge CB3 OET, UK

165 - Serviço do Parque Natural da Madeira, Secretaria Regional do Ambiente e dos

17 Recursos Naturais, Funchal, Portugal.

18

19 * Correspondence: Paulo Catry. Tel: (351) 96 2445005. Email: paulo.catry@ gmail.com

20

21

22 Running title: Activity levels in old Shearwaters 


\section{Abstract}

25 It has long been known that birds change their behaviour, reproductive performance and survival as they mature, including in the first few years after recruitment into the breeding population. However, and contrasting with the description of patterns of actuarial and reproductive senescence in latter years, there are surprisingly few studies documenting changes in behaviour in old individuals. Such studies are important, as birds provide particularly interesting models for studying the biology of senescence. It has been suggested that unlike mammals, birds may remain physically fit until an advanced age, yet this has limited empirical support. In this paper, we used activity (immersion) loggers to show that old (>26 years) Cory's Shearwaters Calonectris diomedea are less active when foraging at sea, spend more time resting on the water and have a smaller number of take-offs and landings during darkness, when compared to experienced mid-aged individuals (13-20 years old). Old individuals also tended to have reduced immune response against an experimental challenge using phytohaemagglutinin. These results are in line with observed reductions in activity levels with age in a wide range of non-avian taxa, and may suggest that old seabirds are physically less fit than younger individuals. Alternatively, old birds might simply be more experienced and their reduction in activity might reflect a strategic regulation of investment in different activities. Our study illustrates the potential for gaining insights into avian aging patterns and processes by looking into the behaviour of model organisms. We therefore encourage more research focusing on behavioural parameters that may reflect variations in physical condition or strategic choices, during both the breeding and non-breeding seasons. 
50 Nimms' leicht oder Ermüdung: Alte Gelbschabel-Sturmtaucher zeigen reduzierte $51 \quad$ Aktivität auf See.

53 Es ist bereits seit längerem bekannt, dass sich das Verhalten, der Bruterfolg und die

54 Überlebensrate von Vögeln mit zunehmendem Alter verändert. Trotz der Beschreibung 55 solcher Muster von Sterblichkeits- und reproduktiver Vergreisung in späteren Jahren 56 gibt es erstaunlich wenige Studien, die eine derartige Veränderung im Verhalten alter Individuen dokumentieren. Solche Studien sind wichtig, weil Vögel ein besonders interessantes Modellsystem für die Untersuchung der Biologie von Vergreisung darstellen. Anders als bei Säugetieren wurde vorgeschlagen, dass Vögel bis ins hohe Alter physisch gesund bleiben. Dies wird jedoch nur im begrenzten Maße von empirischen Daten unterstützt. In der vorliegenden Studie verwendeten wir Aktivitätslogger, um zu zeigen, dass 26-jährige Gelbschnabel-Sturmtaucher Calonectris diomedea weniger aktiv sind, während sie auf See furagieren. Sie haben kürzere Ruhepausen auf dem Wasser und eine geringere Anzahl Starts und Landungen während der Dunkelheit, im Vergleich mit erfahrenen mittel alten Individuen (13-20 Jahre alt). Alte Individuen neigten auch zu einer reduzierten Immunreaktion auf eine experimentelle Injektion von Phytohaemagglutinin. Diese Ergebnisse stimmen im Wesentlichen überein mit der beobachteten Abnahme von Aktivität mit zunehmendem Alter in einer großen Anzahl anderer Tiergruppen. Es kann sein, dass alte Seevögel physisch weniger fit sind als jüngere. Alternativ könnten ältere Vögel auch erfahrener sein, und die Aktivitätsreduktion könnte eine strategische Regulierung der Allokation von Investment in unterschiedliche Aktivitäten sein. Unsere Untersuchung zeigt, dass detaillierte Studien des Verhaltens von Modellorganismen das Potential haben, Muster und Alterungsprozesse bei Vögeln zu erklären. Wir regen deshalb mehr Verhaltensstudien an, die die Variation in der physischer Kondition oder verschiedene strategischen Entscheidungen reflektieren, und dies sowohl in wie außerhalb der Brutsaison. 


\section{Introduction}

82 In recent decades, many studies have focused on age-related changes in the behaviour

83 and fitness of birds. Some general trends are now relatively well-established. For

84 example, in the first months or years of life, birds apparently improve their foraging

85 efficiency (Wunderle 1991), dominance-mediated competitive ability (Sergio et al.

86 2009), migratory performance (Thorup et al. 2003), and breeding success and survival

87 (Newton 1989). Such changes are apparent in cross-sectional studies and result not only

88 from the selective appearance and disappearance of phenotypes, but also, as

89 longitudinal analyses indicate, from the acquisition of relevant experience (Forslund and

90 Pärt 1995).

91 Changes in behaviour may also occur at a more advanced age and could result

92 from strategic choices, as predicted by classic life-history theory. This includes, for

93 example, that in their last breeding attempt, individuals should raise their reproductive

94 effort in order not to waste unused resources (Stearns 1992). However, recent

95 theoretical research suggests that increased parental investment may not be adaptive

96 before the terminal breeding attempt, and that instead, a reduction in reproductive effort

97 should be typical response to an advancing age (McNamara et al. 2009). Furthermore, in

98 the last breeding attempt, it is possible that birds are already somewhat debilitated by a

99 rapidly advancing terminal disease (Ricklefs 2000, 2008, Coulson and Fairweather

100 2001), which would hinder the detection of an increased terminal effort. In fact, only a

101 handful of experimental studies have found evidence for the terminal investment

102 hypothesis (e.g. Hanssen 2006, Velando et al. 2006).

103 Studies to date have either documented actuarial senescence (Ricklefs 2000), or,

104 if they dealt with loss of function in old individuals, have mostly focused on

105 reproduction (e.g. Bennett and Owens 2002, Jones et al. 2008). This reflects the desire 
106 to understand age-specific reproductive performance in relation to life-history theory,

107 and also the relative ease with which relevant parameters can be measured. However,

108 reproductive performance may be affected by a number of external factors, such as the

109 quality of the nesting partner or changes in the environment, which confound

110 interpretation (Nisbet 2001). Therefore, measuring other aspects of individual state and

111 performance may contribute to a better understanding of the mechanisms of aging, and

112 hence of the biology of senescence. Although there has been recent research focusing on

113 hormonal, physiological and cellular parameters (Haussmann et al. 2005, Vleck et al.

114 2007), surprisingly few studies have explored the effects of aging of wild animals on

115 traits such as foraging behaviour and efficiency (but see Catry et al. 2006, MacNulty et

116 al. 2009, Lecomte et al. 2010). Such traits are highly relevant because they influence the

117 rate of resource acquisition, and hence have major implications for fitness correlates

118 that include reproductive output and survival.

119 Declines in activity levels of old individuals have been described for taxa

120 ranging from nematodes and insects, to rodents, dogs and primates (e.g. Emborg et al.

121 1998, Fernández et al. 1999, Siwak et al. 2002, see Sallis 2000 and Ingram 2000 for

122 reviews). Such declines are more obvious for demanding actions that require higher

123 energetic expenditure or greater motor coordination, and, at least in mammals, seem to

124 have a biological basis, resulting from impaired motor and neurobiological function,

125 rather than a simple adaptive reduction in motivation or as an effect of social influences

126 (Emborg et al. 1998, Ingram 2000, Carter et al. 2002, Némoz-Bertholet and Aujard

127 2003). Few studies of wild birds have attempted to measure activity levels in relation to

128 aging, but very old male Grey-headed Albatrosses Thalassarche chrysostoma were

129 reported to display reduced foraging efficiency when compared to mid-aged individuals,

130 which suggests a deterioration in physical performance (Catry et al. 2006). Furthermore, 
131 in Wandering Albatrosses Diomedea exulans, differences were found in the at-sea

132 activity budgets and distribution of mid-age and old male individuals, and old birds had

133 higher levels of the stress hormone corticosterone after a foraging trip (Lecomte et al.

134 2010). These results contrasts with recent suggestions that birds remain physically fit

135 into old age (Ricklefs 2000, 2008). Clearly this is an interesting question that deserves

136 further attention.

137 New data logger systems are revolutionising our ability to continuously monitor

138 bird behaviour, including in species such as seabirds whose pelagic lifestyles were

139 formerly largely unknown (Ropert-Coudert and Wilson 2005). Seabirds are particularly

140 useful models for studying age-related changes in ecology and behaviour, given their

141 unusual longevity and the ease with which they can be marked (ringed), such that many

142 individuals are of known age in populations subject to long-term study (Wooller et al.

143 1992). Cory's Shearwaters Calonectris diomedea are medium-sized seabirds that

144 typically forage for fish and squid in the upper levels of the pelagic domain. While one

145 bird incubates, the partner engages in long foraging trips that normally last for several

146 days and can take the off-duty individual to hundreds of kilometres from the nesting

147 site. Here we report a study on the activity levels and water mass selection of foraging

148 Cory's Shearwaters of known age.

149 We were particularly interested in exploring the possibility that old individuals

150 might suffer from some form of physical senescence effects that could affect their at-sea

151 distribution or foraging behaviour. If so, we would make the following predictions: (1)

152 old individuals should spend more time resting on the water during a foraging trip

153 (Passos et al. 2010), and (2) old birds should perform a smaller number of take-offs and

154 landings, as these are known to be energy-demanding activities in medium to large

155 sized petrels (Weimerskirch et al. 2000, Shaffer et al 2001). If the first two predictions 
156 are confirmed, we would also predict as a corollary that (3) old individuals should take

157 longer to recover body mass lost in incubation and hence make longer foraging trips. It

158 is important to note from the outset that similar patterns (predictions 1 and 2) could be

159 observed if old birds were simply more efficient, allowing them more discretionary

160 resting time than mid-aged individuals. Hence, in this respect our study is exploratory,

161 as to attribute any detected changes to senescence requires more detailed, longitudinal

162 analyses. Our aim is therefore primarily to identify variables that deserve scrutiny in

163 future research.

164

165 Methods

166 This study took place at Selvagem Grande, Savage islands $\left(30^{\circ} 09^{`} \mathrm{~N}, 15^{\circ} 52^{`} \mathrm{~W}\right)$, where a

167 large colony (currently ca 30,000 pairs) of Cory's Shearwaters has been the object of

168 long-term research (Mougin et al. 2000, Granadeiro et al. 2006). Cory's Shearwaters

169 nest in burrows and incubate their single egg for a period of ca 54 days (Thibault et al.

170 1997). In some parts of the colony, chicks and breeding adults have been marked with

171 monel rings on the leg since 1977. In June 2007, during early incubation, we searched

172 those sectors for individuals ringed as chicks, and therefore of known age. To increase

173 sample sizes, we also selected birds that had been ringed as adults in 1977-87 and hence

174 were of considerably advanced age. On average, Cory's Shearwaters start nesting at 8.9

$175 \pm 1.7$ years and fewer than $1 \%$ of the individuals do so before the age of 6 (Mougin et

176 al. 2000), hence these birds would have been at least 26 years old by the time of our

177 study. Based on previous studies of senescence in this population that reported declines

178 in breeding success for birds older than 25 years (Mougin 2002), we defined two groups

179 of ringed birds, as follows: "Old" individuals were those ringed as chicks (40\%) or

180 adults $(60 \%)$ and, respectively, known or assumed to be at least 26 years old, and "Mid- 
181 aged" individuals were those aged 13-20 years (the majority were 13-16 years old).

182 These groups were defined a priori (i.e. before subsequent study).

183 In the last week of June 2007, we deployed activity and temperature loggers on

184 incubating birds. The loggers (Mk 7; British Antarctic Survey, Cambridge) weigh only

$1853.5 \mathrm{~g}$ and were attached to the monel ring using a plastic, weather-resistant cable-tie.

186 These loggers record a single sea-surface temperature (SST) value after $20 \mathrm{~min}$. of

187 continuous immersion, and will only record a new value after a subsequent dry period,

188 followed by immersion for a further $20 \mathrm{~min}$. They also record the timings of all changes

189 of state (from wet to dry, and vice versa) of $6 \mathrm{~s}$ or more, allowing the reconstruction of

190 detailed activity patterns. These loggers are not known to have any significant

191 deleterious effects (Igual et al. 2005). Loggers were recovered 3 to 4 weeks later, by

192 which time all individuals had performed at least one foraging trip. The recovery rate 193 was $96 \%$.

194 The approximate start and end date of each foraging trip (which typically lasted

195 several days, see results) could be estimated from the first and last wet event between

196 incubation stints (Edwards et al. 2007). However, after leaving its nest, a bird could

197 potentially fly for several hours before landing on the water, which would be

198 indistinguishable from time spent at the nest, as would the last flight at the end of the

199 foraging trip. Hence, when estimating number of hours flying or resting on the water

200 per day, we excluded information on the first and the last day of the foraging trip.

201 During a foraging trip, birds spent most of the night on the water. On rare occasions,

202 loggers recorded a long continuous dry period during the night, which could result from

203 the bird attending the colony, rather than represent time in flight. To avoid the

204 disproportionate influence of these rare events, we used median values, rather than

205 means, when calculating summary statistics for individuals. 
207 light levels related to the moon phase (Yamamoto et al. 2008). To assess if this factor

208 might confound our results, we compared the likely light levels experienced by Mid-

209 aged and Old individuals by the use of a moon score. A night with full moon was given

210 a score 15 , while the new moon had a score 0 , with intermediate dates having

211 intermediate scores, between 1 and 14. We then calculated the median score

212 experienced by each individual during the nights it was out at sea and finally compared

213 the two age-groups. This analysis is unlikely to be further confounded by cloud-cover,

214 as only thin clouds were occasionally present during the study. Furthermore, departure

215 date had no influence on the behavioural variables measured and when we repeated the

216 analyses statistically controlling for departure date, the patterns reported in this paper

217 remained unchanged.

218 To assess potential differences in selection of foraging areas, we calculated the

219 mean logger SST value for each bird during darkness (to avoid direct effects of sunlight

220 on the loggers) on each day, took the mean of those values during each foraging trip,

221 and then compared this between between Old and Mid-aged groups.

222 In our analyses, we deliberately excluded birds that might be affected by an

223 advanced terminal illness (Catry et al. 2006). Survival rates of Cory's Shearwaters are

224 typically high and only a few individuals were not resighted in the following year.

225 These birds may have died in the intervening period, or be deferring breeding. This

226 small sample was insufficient for exploring patterns relating to terminal investment, but

227 could introduce considerable noise in the data sets. Hence, analyses presented here

228 focus exclusively on birds that were resighted in the season following our field

229 measurements. 
231 Shearwaters aged above 25 years old displayed a decline in reproductive function

232 consistent with senescence. To further assess whether our group of Old birds showed

233 physiological evidence of senescence, we evaluated their immune status by means of

234 the phytohaemagglutinin (PHA) test (Smits et al. 1999, Haussmann et al. 2005,

235 Kennedy and Nager 2006). This test consists of injecting a mitogen (PHA) and

236 measuring the swelling at the injection site 24 hours later. The swelling results from a

237 perivascular accumulation of T lymphocytes followed by macrophage infiltration (Smits

238 et al. 1999), and its measurement is thought to provide an indication of the T-cell

239 mediated immune response.

240 We attempted to use the same procedure as Forero et al. (2006), which involved

241 the injection of a solution of PHA into the foot-web and measurement of subsequent

242 swelling. However, we were unsuccessful at web injections and instead injected $0.05 \mathrm{ml}$

243 of $2 \mathrm{mg} \mathrm{ml}^{-1}$ PHA (Sigma) in phosphate-buffered saline (PBS) at a marked point on the

244 tarsus. Three measurements of tarsus thickness over the injection point were made

245 before and 24 hours after the injection using an electronic Mitutoyo micrometer

$246( \pm 0.01 \mathrm{~mm})$. From these, we calculated three different PHA response measures to assess

247 the repeatability of our estimates, which was high $\left(r=0.87, F_{64,194}=20.1, P<0.001\right)$.

248 We then averaged the three measurements before and the three measurements after and

249 calculated a final PHA response value based on this difference.

250 Study birds were sexed using a discriminant function based on bill

251 measurements (Granadeiro 1993). Individuals with a score $>0.1$ were classified as

252 males and those with a score $<-0.1$ as females. Birds with intermediate values were

253 sexed if paired with an individual of known sex, or if their distinctive vocalizations 
254 (Thibault et al. 1997) were heard during handling. By using these criteria, and cross-

255 validation with nesting partners, sex classification accuracy was $>99 \%$ (unpubl. data).

$256 \quad$ Variables related to the number of take-offs and landings were log-transformed

257 to meet the requirements of normality and homogeneity of variances. Means are

258 presented \pm SD.

260 Results

261 Sex had no influence on foraging trip variables reported below and hence this factor was excluded from all models. During foraging trips, Mid-aged individuals took off and landed more often than did Old individuals (Fig. 1). This difference was only significant

264 during darkness (Table 1). The proportion of time spent resting on the water was higher

265 in Old individuals, again with the most pronounced differences observed during darkness (Table 1). There were no differences between age groups in foraging trip duration, mean daily SST values or absolute minimum SST values attained during the trip (Table 1). Trip duration correlated negatively with minimum SST values $(r=-0.53$, $\mathrm{n}=33, \mathrm{P}=0.001$ ), indicating that only on longer trips did birds reach the cold waters of the Canaries upwelling, near the African coast (own unpubl. data). This illustrates the usefulness of SST as an indicator of foraging region. Sex had no influence on PHA response and hence was excluded from the model.

273 Cory's Shearwaters from the Old group had a weaker PHA response $(0.663 \pm 0.423$

$274 \mathrm{~mm}, \mathrm{~N}=33)$ than Mid-aged individuals $\left(0.853 \pm 0.451 \mathrm{~mm}, \mathrm{~N}=32\right.$; ANOVA $\mathrm{F}_{1,64}=$

$2753.06, \mathrm{P}=0.085)$. Note that the difference is significant if we adopt a one-tailed test, in accordance with our directional prediction that senescent animals should show a depressed immune response. 


\section{Discussion}

280 The concept that, unlike mammals such as humans, birds may remain physically fit until 281 old age (Ricklefs 2000, 2008) has seldom been tested (but see Coulson and Fairweather

282 2001, Catry et al. 2006), despite its importance in the context of the biology of

283 senescence. The results from the present work, and the ones from a recent study with

284 albatrosses (Lecomte et al. 2010), suggest that old, free-living seabirds display a

285 reduction in activity levels that parallels patterns reported for a diversity of other taxa

286 (e.g. Emborg et al. 1998, Fernández et al. 1999, Ingram 2000, Siwak et al. 2002,

287 Némoz-Bertholet and Aujard 2003). The causes for such reduction in activity levels are

288 so far unknown, but circumstantial evidence suggests that senescence due to progressive

289 wear and tear (somatic deterioration) of aging bodies is a strong candidate explanation.

290 For medium to large petrels that rely on wind-assisted dynamic soaring for travel, flight is often considered to be a relatively economical activity, only slightly more costly than resting: instead, most of the variation in energy expenditure during

293 foraging trips of albatrosses is explained by the number of take-offs, which are

294 energetically expensive (Bevan et al. 1995, Weimerskirch et al. 2000, Shaffer et al 295 2001). However, those studies involved birds that proceed by flap-gliding in the windy southern ocean and it is likely that flight is much more costly for Cory's Shearwaters,

297 which are frequently seen using flapping flight.

The discovery that Old Cory's Shearwaters differed from Mid-aged individuals

299 mostly in the number of take-offs and landings fits well with evidence from other taxa

300 that declines in spontaneous activity are more pronounced in the frequency of

301 demanding physical tasks. For example, in Grey Mouse Lemurs Microcebus murinus, 
303 jumps, where an intense physical effort was required (Némoz-Bertholet and Aujard 304 2003).

Petrels are known to both travel and forage during darkness as well as daylight,

306 although they tend to be more active during the latter (Catry et al. 2004, Phalan et al.

307 2007, this study). The disproportionate reduction of activity among old Shearwaters

308 during darkness might reflect a strategy to avoid demanding activities when they are

309 less likely to yield a benefit, given that foraging at night seems to be less profitable for

310 visual predators such as seabirds (Catry et al. 2004). An experimental study with Cory's

311 Shearwaters showed that handicapped birds (carrying extra mass) also reduced their

312 activity levels (less time spent flying) during darkness (Passos et al. 2010). It seems less

313 likely that Old birds sleep more during darkness, as sleep is more often interrupted in

314 aged animals (e.g. Hornung et al. 2005), including birds (Paredes et al. 2006). That sea

315 surface temperatures in feeding areas and foraging trip duration were similar in Mid-

316 aged and Old individuals, suggests that differences in activity levels between age groups

317 cannot be explained by disparate habitat preferences.

318 The decline in the PHA response by aged Cory's Shearwaters is consistent with

319 results from recent studies indicating that immunosenescence may be common in both

320 short and long-lived bird species (Haussmann et al. 2005, Vleck et al. 2007). It also

321 suggests that our Old birds in our study had reached an age where senescence effects

322 might be apparent (see also Mougin 2002).

323 There are alternative explanations to deterioration in physical function for the

324 observed declines in activity. Old individuals were not forced to prolong their foraging

325 trips as a result of their lower activity levels, and it is therefore possible that they were

326 more efficient at foraging as a result of accumulated experience. In this context, it

327 should be mentioned that the handicapped (carrying extra mass) Cory's shearwaters 
studied by Passos et al. (2010), and alluded to above, did make longer foraging trips, which may suggest that this is a relevant variable when studying performance during foraging movements.

Both the activity and the immune response trends presented in this paper result

332 from cross-sectional analyses. Cross-sectional studies have limitations, because patterns

333 may result from cohort heterogeneity or even individual heterogeneity in longevity and

334 other parameters of interest (Nisbet 2001). However, as far as we are aware, no study

335 has demonstrated that differential mortality of phenotypes is responsible for apparent

336 senescence in breeding performance in long-lived birds. Hence, despite this being a

337 possibility, it is relatively unlikely to have influenced our results. Nevertheless, the

338 hypotheses tested in this study should be further evaluated using longitudinal data sets.

339 Neither can we discard the idea that old individuals might be strategically reducing their

340 parental effort (McNamara et al. 2009). This explanation could be ruled out in our case

341 by determining if differences in individual activity patterns persist during the

342 nonbreeding season.

343 In conclusion, our study demonstrates the potential for gathering insights into

344 avian senescence patterns and processes by looking beyond the classical variables of

345 adult mortality and breeding output. We would therefore encourage more research

346 focusing on parameters that reflect physical performance and behaviour, both in the

347 breeding and non-breeding seasons.

\section{Acknowledgements}

350 Parque Natural da Madeira, and particularly Dília Menezes provided permissions to 351 carry out the work and, together with the wardens at the Nature Reserve where this 352 study took place, gave important logistical support. Hany Alonso, Rafael Matias, Maria 
353 Dias, Miguel Lecoq, Rui Rebelo, Filipe Moniz, Ana Leal, Ricardo Martins and others

354 helped with fieldwork. The manuscript benefited from the comments of two anonymous

355 referees. This study is an output from a project on the ecology and senescence in Cory's

356 Shearwaters (PDCT/MAR/58778/2004) supported by Fundação para a Ciência e a

357 Tecnologia (FCT - Portugal) and FEDER. P. Catry benefited from postdoctoral

358 fellowships from FCT (BPD/11631/02 and SFRH/BPD/30031/2006) and further

359 support was received through Programa Plurianual (UI\&D 331/94).

360

$361 \quad$ References

362 Bennett PM, Owens IPF (2002) Evolutionary Ecology of Birds. Oxford University Press, Oxford

364 Bevan RM, Butler PJ, Woakes AJ, Prince PA (1995) The energy expenditure of freeranging black-browed albatrosses. Phil Trans R Soc Lond B 350:119-131

366 Carter CS, Sonntag WE, Onder WE, Pahor M (2002) Physical performance and longevity in aged rats. J Gerontol 57:B193-B197

Catry P, Phillips RA, Phalan B, Silk JRD, Croxall JP (2004) Foraging strategies of grey-headed albatrosses Thalassarche chrysostoma: integration of movements, activity and feeding events. Mar Ecol Progr Ser 280:261-273

371 Catry P, Phillips RA, Phalan B, Croxall JP (2006) Senescence effects in an extremely long-lived bird: the grey-headed albatross Thalassarche chrysostoma. Proc $\mathrm{R}$ Soc B 273:1625-1630

374 Coulson JC, Fairweather JA (2001) Reduced reproductive performance prior to death in 375 the Black-legged Kittiwake: senescence or terminal illness? J Avian Biol $32: 146-152$ 
Edwards AM, Phillips RA, Watkins NW, Freeman MP, Murphy EJ, Afanasyev V, Buldyrev SV, da Luz MGE, Raposo EP, Stanley HE, Viswanathan GM (2007) Overturning evidence of Levy flight searches by wandering albatrosses, bumblebees and deer. Nature 449:1044-1049

Emborg ME, Ma SY, Mufson EJ, Levey AI, Taylor MD, Brown WD, Holden JE Kordower JH (1998) Age-related declines in nigral neuronal function correlate with motor impairments in rhesus monkeys. J Comp Neurol 401:253-265

Fernández JR, Grant MD, Tulli NM, Karkowski LM, McClearn GE (1999) Differences in locomotor activity across the lifespan of Drosophila melanogaster. Exp Gerontol 34:621-631

Forero MG, González-Solis J, Igual JM, Hobson KA, Ruíz X, Viscor G (2006) Ecological and physiological variance in T-cell mediated immune response in Cory's Shearwaters. Condor 108:865-876

Forslund P, Pärt T (1995) Age and reproduction in birds - hypotheses and tests. Trends Ecol Evol 10:374-378

Granadeiro JP (1993) Variation in measurements of Cory's Shearwater between populations and sexing by discriminant analysis. Ring Migr 14:103-112

Granadeiro JP, Dias MP, Rebelo R, Santos CD, Catry P (2006) Numbers and population trends of Cory's Shearwater Calonectris diomedea at Selvagem Grande, Northeast Atlantic. Waterbirds 29:56-60

Hanssen SA (2006) Cost of an immune challenge and terminal investment in a longlived bird. Ecology 87:2440-2446

Haussmann MF, Winkler DW, Huntington CE, Vleck D, Sanneman CE, Hanley D, Vleck CM (2005) Cell-mediated immunosenescence in birds. Oecologia $145: 270-275$ 
402 Hornung OP, Danker-Hopfe H, Heuser I (2005) Age-related changes in sleep and memory: commonalities and interrelationships. Exp Gerontol 40:279-285

404 Igual JM, Forero MG, Tavecchia G, González-Solis J, Martínez-Abraín A, Hobson KA, 405 Ruiz X, Oro D (2005) Short-term effects of data-loggers on Cory’s Shearwaters Calonectris diomedea. Mar Biol 146:619-624

407 Ingram DK (2000) Age-related decline in physical activity: generalization to 408 nonhumans. Med Sci Sports Exerc 32:1623-1629

Jones OR and 34 co-authors (2008) Senescence rates are determined by ranking on the fast-slow life-history continuum. Ecol Lett 11:664-673

Kennedy MW, Nager MG (2006) The perils and prospects of using phytohaemagglutinin in evolutionary ecology. Trends Ecol Evol 21:653-655

413 Lecomte VJ, Sorci G, Cornet S, Jaeger A, Faivre B, Arnoux E, Gaillard M, Trouvé C, Besson D, Chastel O, Weimerskirch H (2010) Patterns of aging in the long-lived wandering albatross. Proc Nat Acad Sci 107:6370-6375

MacNulty DR, Smith DW, Vucetich JA, Mech LD, Stahler DR, Packer C (2009) Predatory senescence in ageing wolves. Ecol Lett 12:1347-1356.

418 McNamara JM, Houston AI, Barta Z, Scheuerlein A, Fromhage L (2009) Deterioration, 419 death and the evolution of reproductive restraint in late life. Proc R Soc B 276:4061-4066

Mougin J-L (2002) Influence de la sénilité sur la réussite de la reproduction chez le puffin cendré Calonectris diomedea. Bol Mus Mun Funchal 53 :27-34

Mougin J-L, Jouanin C, Roux F (2000) Démographie du puffin cendré Calonectris diomedea de Selvagem Grande. Rev Ecol (Terre Vie) 55:275-290 
Némoz-Bertholet F, Aujard F (2003) Physical activity and balance performance as a function of age in a prosimian primate (Microcebus murinus). Exp Gerontol $38: 407-414$

Newton I (ed.) (1989) Lifetime reproduction in birds. London, Academic Press.

Nisbet ICT (2001) Detecting and measuring senescence in wild birds: experience with long-lived seabirds. Exp Gerontol 36:833-843

Paredes SD, Terrón MP, Cubero J, Valero V, Barriga C, Reiter RJ, Rodríguez AB (2006) Comparative study of the activity/rest rhytms in young and old ringdove (Streptopelia risoria): correlation with serum levels of melatonin and serotonin. Chronobiol Internat 23:779-793

Passos C, Navarro J, Giudici A, González-Solís J (2010) Effects of extra mass on the pelagic behavior of a seabird. Auk 127:100-107

Phalan B, Phillips RA, Silk JRD, Afanasyev V, Fukuda A, Fox J, Catry P, Higuchi H, Croxall JP (2007) Foraging behaviour of four albatross species by night and day. Mar Ecol Progr Ser 340:271-286

Ricklefs RE (2000) Intrinsic aging-related mortality in birds. J Avian Biol 31:103-111

Ricklefs RE (2008) The evolution of senescence from a comparative perspective. Funct Ecol 22: 379-392

Ropert-Coudert Y, Wilson RP (2005) Trends and perspectives in animal-attached remote sensing. Front Ecol Environ. 3:437-444

Sallis JF (2000) Age-related decline in physical activity: a synthesis of human and animal studies. Med Sci Sports Exerc 32:1598-1600

Sergio F, Blas J, Hiraldo F (2009) Predictors of floater status in a long-lived bird: a cross-sectional and longitudinal test of hypotheses. J Anim Ecol 78:109-118 
Shaffer SA, Costa DP, Weimerskirch H (2001) Behavioural factors affecting foraging effort of breeding wandering albatross. J Anim Ecol 70:864-874

Siwak CT, Murphey HL, Muggenburg BA, Milgram NW (2002) Age-dependent decline in locomotor activity in dogs is environment specific. Physiol Behav 75:65-70

Smits JE, Bortolotti GR, Tella JL (1999) Simplifying the phytohaemagglutinin skintesting technique in studies of avian immunocompetence. Funct Ecol 13:567572

Stearns SC (1992) The evolution of life histories. Oxford University Press, Oxford.

Thibault J-C, Bretagnolle V, Rabouam C (1997) Calonectris diomedea Cory's Shearwater. BWP Update 1:75-98

Thorup K, Alerstam T, Hake M, Kjellén M (2003) Bird orientation: compensation for wind drift in migrating raptors is age dependent. Proc R Soc Lond B (Suppl.) 270:S8-S11

Velando A, Drummond H, Torres R (2006) Senescent birds redouble reproductive effort when ill: confirmation of the terminal investment hypothesis. Proc R Soc B 273:1443-1448

Vleck CM, Haussmann ME, Vleck D (2007) Avian senescence: underlying mechanisms. J Orn 148: S611-S624

Weimerskirch H, Guionnet T, Martin J, Shaffer SA, Costa DP (2000) Fast and fuel efficient? Optimal use of wind by flying albatrosses. Proc R Soc Lond B 267:1869-1874 Trends Ecol Evol 7:111-114

472 Wunderle JM (1991) Age-specific foraging proficiency in birds. Curr Ornithol 8:273473 324 
474 Yamamoto T, Takahashi A, Yoda K, Katsumata N, Watanabe S, Sato K, Trathan PN

475

(2008) The lunar cycle affects at-sea behaviour in a pelagic seabird, the Streaked

476 Shearwater Calonectris leucomelas. Anim Behav 76:1647-1652.

477

478

479 
480 Table 1. Characteristics of foraging trips carried out by Mid-aged and Old Cory's

481 Shearwaters during incubation. Number of take-offs and landings and mean sea surface 482 temperature (SST) are means of mean daily values per individual. Proportions of time 483 resting are means of medians of daily values per individual. See text for details.

\begin{tabular}{|c|c|c|c|}
\hline & $\begin{array}{l}\text { Mid-aged birds } \\
\qquad(\mathrm{N}=17)\end{array}$ & $\begin{array}{l}\text { Old birds } \\
(\mathrm{N}=18)\end{array}$ & $\begin{array}{l}\text { Statistical } \\
\text { comparison }\end{array}$ \\
\hline Wet-dry changes & $30.8 \pm 24.0$ & $13.4 \pm 7.2$ & $\mathrm{~F}_{1,34}=12.6$ \\
\hline during darkness & & & $\mathrm{P}<0.001$ \\
\hline Wet-dry changes in & $100.8 \pm 32.7$ & $84.7 \pm 24.5$ & $\mathrm{~F}_{1,34}=0.84$ \\
\hline daylight & & & $P=0.34$ \\
\hline Proportion time & $0.46 \pm 0.13$ & $0.55 \pm 0.13$ & $\mathrm{~F}_{1,34}=3.67$ \\
\hline resting in water & & & $P=0.06$ \\
\hline Resting in water & $0.72 \pm 0.18$ & $0.83 \pm 0.20$ & $\mathrm{~F}_{1,34}=3.96$ \\
\hline during darkness & & & $\mathrm{P}=0.05$ \\
\hline Resting in water & $0.38 \pm 0.14$ & $0.44 \pm 0.12$ & $\mathrm{~F}_{1,34}=1.89$ \\
\hline during daylight & & & $\mathrm{P}=0.18$ \\
\hline Mean SST $\left({ }^{\circ} \mathrm{C}\right)$ & $18.65 \pm 1.10$ & $18.59 \pm 0.62$ & $\mathrm{~F}_{1,34}=0.45$ \\
\hline & & & $\mathrm{P}=0.83$ \\
\hline Minimum SST $\left({ }^{\circ} \mathrm{C}\right)$ & $17.12 \pm 1.25$ & $17.26 \pm 1.16$ & $\begin{array}{c}\mathrm{F}_{1,34}=0.14 \\
\mathrm{P}=0.71\end{array}$ \\
\hline Foraging trip & $9.23 \pm 2.69$ & $8.52 \pm 1.93$ & $\mathrm{~F}_{1,34}=0.76$ \\
\hline duration (days) & & & $P=0.39$ \\
\hline Light levels (median & 7.5 & 9.0 & $\mathrm{M}-\mathrm{W} \mathrm{U}=100.5$ \\
\hline moon score) & & & $\mathrm{P}=0.20$ \\
\hline
\end{tabular}


486 Fig. 1. Box-plots depicting the number of take-offs and landings (per day or night) of

487 Old $(\mathrm{N}=18)$ and Mid-aged $(\mathrm{N}=17)$ Cory's shearwaters. Differences were tested on log488 transformed data (see Table 1 for statistics).

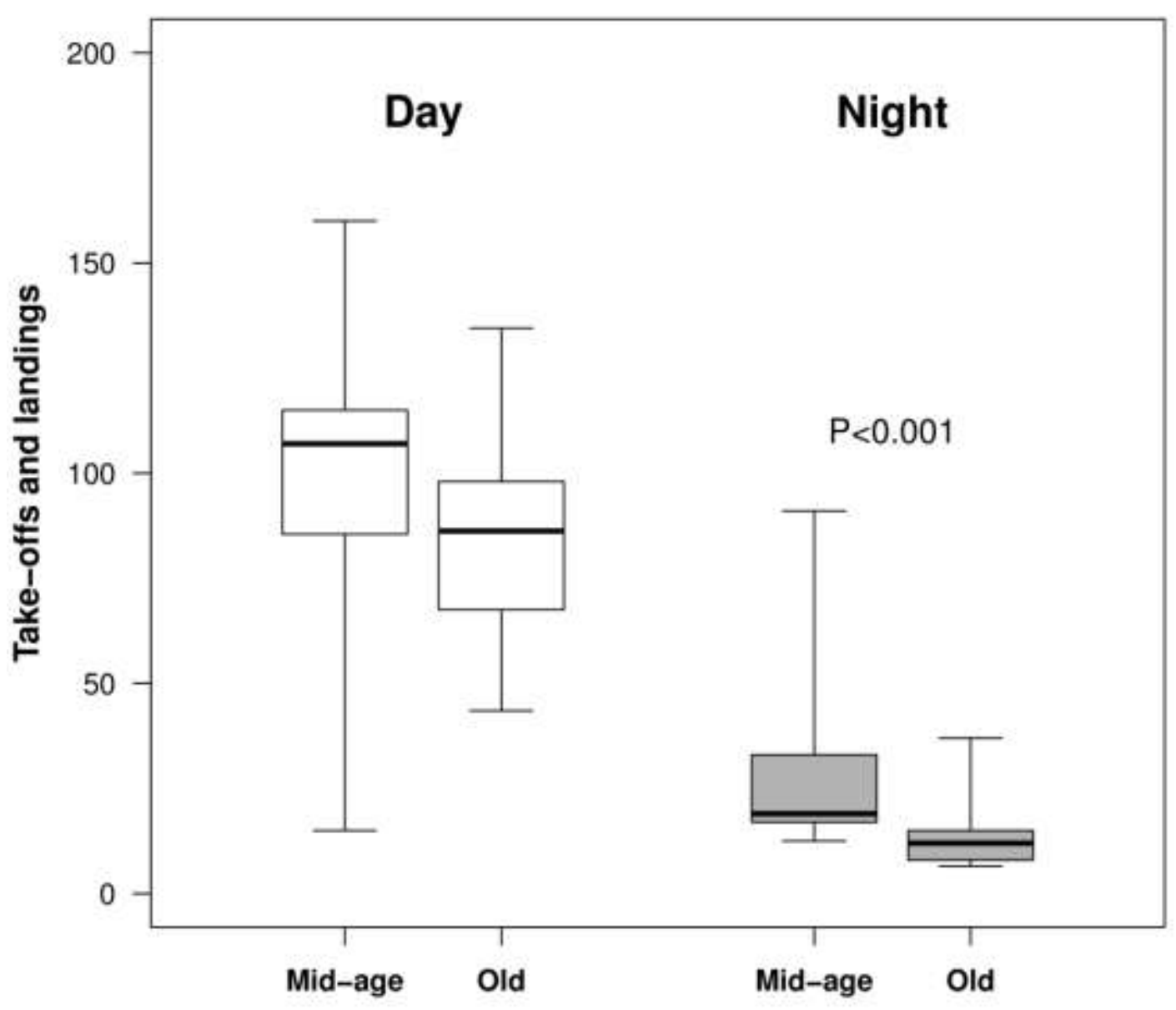

489

490

491

492 